\title{
Mediation of the inhibitory effect of thyroid hormone on proliferation of hepatoma cells by transforming growth factor-beta
}

\author{
Chun-Che Yen, Ya-Hui Huang, Chu-Yu Liao, Cheng-Jung Liao, Wan-Li Cheng, \\ Wei-Jan Chen ${ }^{1}$ and Kwang-Huei Lin
}

Department of Biochemistry, Chang-Gung University, 259 Wen-hwa 1 Road, Taoyuan, Taiwan, Republic of China

${ }^{1}$ First Cardiovascular Division, Chang Gung Memorial Hospital, Taoyuan, Taiwan, Republic of China

(Requests for offprints should be addressed to K-H Lin; Email: khlin@mail.cgu.edu.tw)

\begin{abstract}
Thyroid hormone (triiodothyronine, $\mathrm{T}_{3}$ ) regulates growth, development and differentiation. To examine the influence of $\mathrm{T}_{3}$ on hepatoma cell growth, thyroid receptor (TR) $\alpha 1$ or TR $\beta 1$ over-expressing HepG2 cell lines were used. Growth of the HepG2-TR stable cell line was inhibited by over $50 \%$ following treatment with $\mathrm{T}_{3}$. However, transforming growth factor (TGF)- $\beta$ neutralizing antibody, but not the control antibody can reverse the cell growth inhibition effect of $T_{3}$. Flow cytometric analysis indicated that the growth inhibition was apparent at the transition point between the G1 and S phases of the cell cycle. The expression of major cell cycle regulators was used to provide further evidence for the growth inhibition. Cyclin-dependent kinase 2 (cdk2) and cyclin E were down-regulated in HepG2-TR cells. Moreover, p21 protein or mRNA levels were up-regulated by around 5-fold or 7-3-fold respectively following $T_{3}$ treatment. Furthermore, phospho-retinoblastoma ( $\mathrm{ppRb}$ ) protein was down-regulated by $\mathrm{T}_{3}$. The expression of TGF- $\beta$ was studied to delineate the repression mechanism. TGF- $\beta$ was stimulated by $T_{3}$ and its promoter activity was enhanced six- to eight-fold by $T_{3}$. Furthermore, both $T_{3}$ and TGF- $\beta$ repressed the expression of cdk2, cyclin $E$ and ppRb. On the other hand, TGF- $\beta$ neutralizing but not control antibody blocked the repression of cdk2, cyclin $E$ and $p p R b$ by $T_{3}$. These results demonstrated that $\mathrm{T}_{3}$ might play a key role in liver tumor cell proliferation.
\end{abstract}

Journal of Molecular Endocrinology (2006) 36, 9-21

\section{Introduction}

The thyroid hormone, 3,3',5-triiodo-L-thyronine $\left(\mathrm{T}_{3}\right)$, mediates numerous physiological processes, including embryonic development, cellular differentiation, metabolism and the regulation of cell proliferation (Hulbert 2000, Aranda \& Pascual 2001). $\mathrm{T}_{3}$ controls these processes in most organs. The effects of $\mathrm{T}_{3}$ are mediated by nuclear thyroid hormone receptors (TRs). Moreover, TRs bind to the thyroid hormone response elements (TREs) located upstream from the promoters of target genes to regulate their expression transcriptionally (Hulbert 2000, Aranda \& Pascual 2001). The nature of the transcriptional response is determined by cell type, promoter context, and hormone status (Hulbert 2000, Aranda \& Pascual 2001). In most cases, TRs are transcriptional repressors without their cognate hormone $\left(\mathrm{T}_{3}\right.$ or thyroxine $\left.\left(\mathrm{T}_{4}\right)\right)$ and are turned into activators by ligand binding (Hulbert 2000, Aranda \& Pascual 2001).

Two main types of TRs have been identified, termed TR $\alpha$ and TR $\beta$, which are encoded on human chromosomes 17 and 3 respectively (Cheng 2000,
Aranda \& Pascual 2001). Transcripts of each of these genes undergo alternative promoter choice for generating both the TR $\alpha 1$ and $\alpha 2$ and the TR $\beta 1$ and $\beta 2$ receptor isoforms (Cheng 2000, Hulbert 2000, Aranda \& Pascual 2001).

Regarding previously published results (Lin et al. 2004), transforming growth factor-beta (TGF- $\beta$ ) was stimulated by $\mathrm{T}_{3}$ at the mRNA level. TGF- $\beta$ regulates cell growth and proliferation, and has been shown to block the growth of numerous cell types (De Caestecker 2004). The TGF- $\beta$ receptor includes type 1 and type 2 subunits. These subunits comprise serine-threonine kinases that signal through the smad family of transcriptional regulators. $\mathrm{T}_{3} / \mathrm{T}_{4}$ have been shown to stimulate the proliferation of eukaryotic cells (BarreraHernandez et al. 1999, Aranda \& Pascual 2001). Several studies demonstrated that cyclin D1 induction is an early event in $\mathrm{T}_{3}$-induced hepatocyte proliferation (Pibiri et al. 2001, Alisi et al. 2004). These previous studies indicate that this cyclin may be a common target responsible for mitogenic activity of ligands of nuclear receptors. However, the influence of $\mathrm{T}_{3}$ on human liver tumor cell proliferation is currently unknown although a similar 
observation has been reported in rats (LeddaColumbano et al. 2000).

The liver has long been recognized as a target organ for thyroid hormones. In fact, Chamba et al. (1996) reported that roughly equal quantities of TRal and TR $\beta 1$ protein occur in human hepatocytes (Chamba et al. 1996). HepG2 is a well-differentiated hepatocellular carcinoma cell line without detectable TR protein expression. However, it secretes all 15 plasma proteins and preserves numerous liver-specific functions and thus can serve as an in vitro model (Chang et al. 1983). Consequently, the HepG2 cell line provides a useful model system for studying the influence of $\mathrm{T}_{3}$ on the proliferation of liver tumor cells. The system was recently used to demonstrate that TGF- $\beta$ is regulated by $\mathrm{T}_{3}$ (Lin et al. 2004). This work shows that $\mathrm{T}_{3}$ up-regulates the expression of TGF- $\beta$ and subsequently suppresses liver tumor cell proliferation.

\section{Materials and methods}

\section{Cell culture}

Human hepatoma cell lines, HepG2-TR $\alpha 1 \# 1$, HepG2TR 1 1\#2, HepG2-TR $\beta 1$ and HepG2-Neo, and rat pituitary tumor GC cells were routinely grown in Dulbecco's modified Eagle's medium (DMEM) supplemented with $10 \%$ (v/v) fetal bovine serum. Three TR over-expressing lines, and the control cell line, HepG2-Neo, have been described previously (Lin et al. 2004). The serum was depleted of $T_{3}(\mathrm{Td})$ as described by Samuels et al. (1979). Cells were cultured at $37^{\circ} \mathrm{C}$ in a humidified atmosphere of $95 \%$ air and $5 \% \mathrm{CO}_{2}$.

\section{Flow cytometry}

Flow cytometric analysis was performed as described by Fan et al. (1995). Briefly, cells were harvested via trypsinization and fixed in $75 \%$ ethanol for at least $24 \mathrm{~h}$ at $4{ }^{\circ} \mathrm{C}$. The cells were then washed with PBS containing $1 \%$ BSA (Life Technologies, Inc., Rockville, MD, USA) and incubated with $100 \mu \mathrm{g} / \mathrm{ml}$ RNase A (Sigma, St Louis, MO, USA) and $50 \mu \mathrm{g} / \mathrm{ml}$ propidium iodide (Sigma) for $2 \mathrm{~h}$ at room temperature. Finally, the stained cells were analyzed on a FACS Calibur flow cytometer (Becton Dickinson Immunocytometry Systems, San Jose, CA, USA).

\section{Cell proliferation assay}

Gells were plated on 6 -cm dishes at $2 \times 10^{5}$ cells/dish, with each sample being plated in triplicate. Cells were counted using the Coulter Counter ZM (Coulter Electronics Inc., Luton, Beds, UK).

\section{Immunoblot analysis}

Cell lysates were fractionated using SDS-polyacrylamide gel electrophoresis (PAGE) on a 10\% gel, and the separated proteins were transferred to a nitrocellulose membrane (Pall Life Sciences, Ann Arbor, MI, USA) and subsequently visualized via chemiluminescence using an ECL detection kit (Amersham Inc., Piscataway, NJ, USA) as described previously (Shih et al. 2004). The antibodies used were rabbit polyclonal antibodies to cyclin E, and retinoblastoma (Rb) (Santa Cruz Biotechnology, Santa Cruz, CA, USA) or mouse monoclonal antibody to cdk2 (1:1000 dilution in PBS) (Santa Cruz Biotechnology) or TGF- $\beta$ (1:500-1000 dilution in PBS) (Serotec Ltd, Oxford, Oxon, UK). TGF- $\beta_{1}$ was purchased from Pepro Techec (London, UK).

\section{Northern blot analysis}

Total RNA was extracted from the cells using TRIzol Reagent (Life Technologies) and equal amounts of total RNA $(20 \mu \mathrm{g})$ were analyzed on a $1 \cdot 2 \%$ agaroseformaldehyde gel as described previously (Lin et al. 2000, 2002). The separated RNA molecules were then transferred to a nylon membrane (Amersham) and subjected to northern blot analysis as described previously (Lin et al. 2004, Shih et al. 2004).

\section{Quantitative reverse transcription-polymerase chain reaction (Q-RT-PCR)}

Total RNA was extracted from cells using TRIzol, as described above. Subsequently, cDNA was synthesized using the Superscript II kit for RT-PCR (Life Technologies) as described previously (Shih et al. 2004).

Real-time Q-RT-PGR was performed in a 25- $\mu$ l reaction mixture containing $50 \mathrm{nM}$ forward and reverse primers, $1 \times$ Syber Green reaction mix (Applied Biosystems, Werrington, UK), and various quantities of template as described previously (Shih et al. 2004). Fluorescence emitted by Syber Green was detected using the ABI PRISM 7000 sequence detection system (Applied Biosystem), as described previously (Lin et al. 2004, Shih et al. 2004).

\section{Cloning the TGF- $\beta 5^{\prime}$-flanking region and promoter activity assay}

Fragments of the TGF- $\beta$ promoter (nucleotides $-1362 /+101)$ were amplified via PCR, according to the published nucleotide sequence (Kim et al. 1989a,b), and were then inserted into the pGL3 vector (Promega Corp., Madison, WI, USA). The sequence of the promoter construct was confirmed by automated DNA sequencing. To determine the influence of $T_{3}$ on the transcriptional activity of the TGF- $\beta$ promoter, HepG2-TR $\alpha 1 \# 1$ cells $\left(1 \times 10^{5}\right.$ per $35-\mathrm{mm}$ dish $)$ were 


\section{(A) HepG2-Neo}

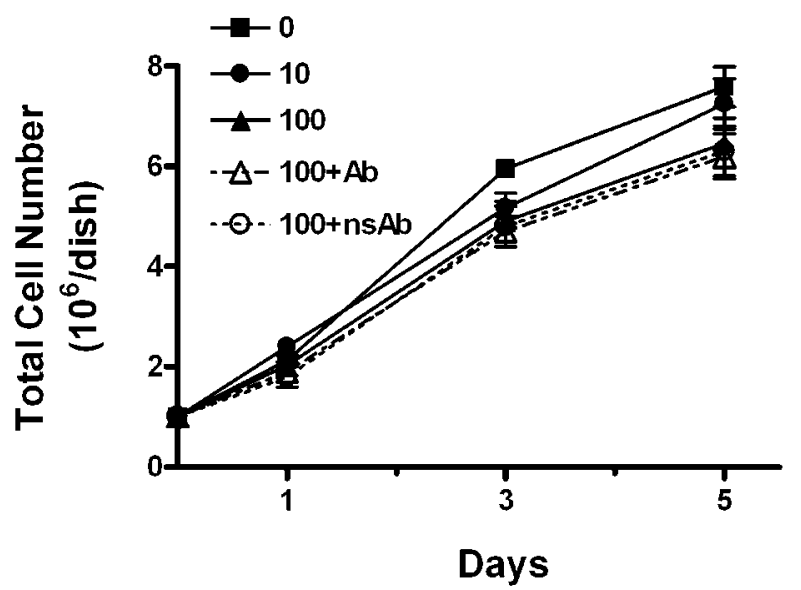

(C) HepG2-TR $\alpha 1 \# 2$

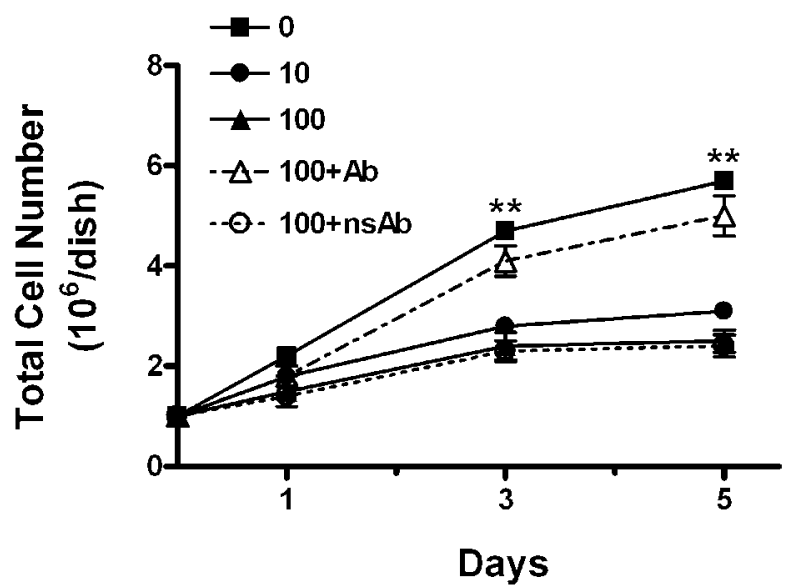

(B) HepG2-TR $\alpha 1 \# 1$

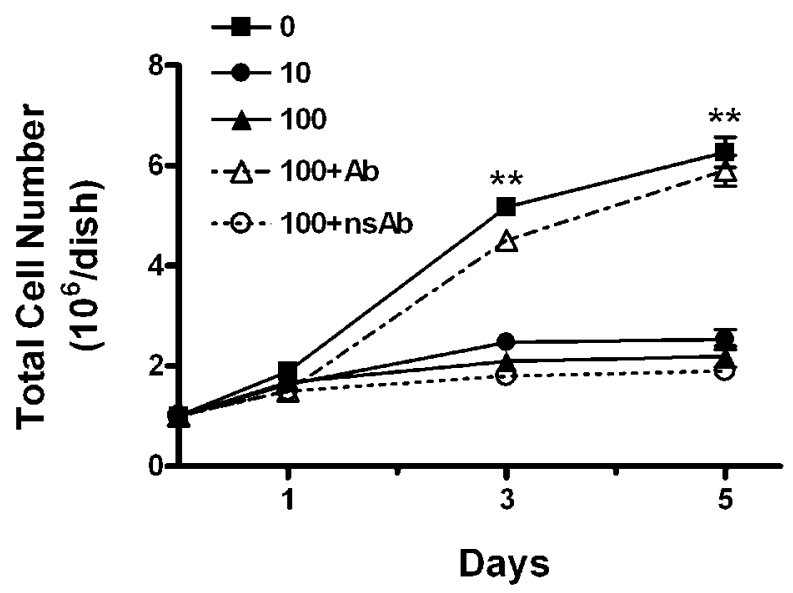

(D) HepG2-TR $\beta 1$

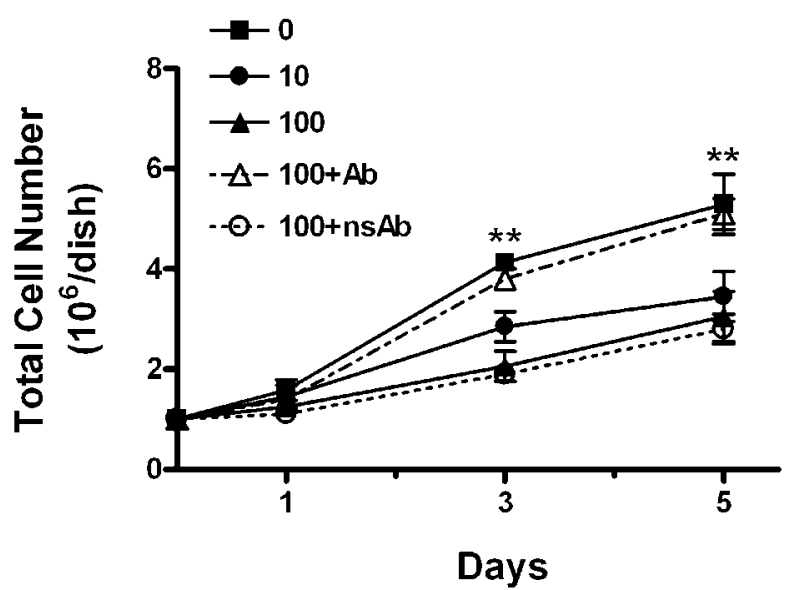

Figure $1 \mathrm{~T}_{3}$ represses the proliferation of HepG2-TR cells. (A) HepG2-Neo, (B) HepG2-TR $1 \# 1$, (C) HepG2-TR $1 \# 2$ or (D) HepG2-TR $\beta 1$ cells were plated in $60-\mathrm{mm}$ dishes at a density of $2 \times 10^{5}$ cells/dish. Cells were incubated with $0(\square), 10(\bullet)$ or 100 (A) $\mathrm{nM} \mathrm{T}_{3}$ for the indicated time. In some experiments, cells were simultaneously incubated with $100 \mathrm{nM} \mathrm{T}_{3}$ and $800 \mathrm{ng}$ of the TGF- $\beta$ neutralizing antibody $(\mathrm{Ab}, \triangle$ ) or non-specific control antibody ( $\mathrm{ns} A \mathrm{~b}, \bigcirc$ ). Subsequently, cell number was determined using the Coulter Counter ZM. Data are expressed as means \pm S.E. of values from three independent experiments. ${ }^{* *} P<0.01,100 \mathrm{nM}$ $\mathrm{T}_{3}$-treated vs Td-treated (0) (Student's $t$-test).

co-transfected, via a Lipofectamine protocol, using $3 \mu \mathrm{g}$ pGL3 vector containing TGF- $\beta$ promoter sequences (Invitrogen) as described previously (Shih et al. 2004).

\section{Results}

\section{$\mathrm{T}_{3}$ represses HepG2-TR 1 and HepG2-TRß1 cell} growth by prolonging the G0/G1 phase

The effect of $\mathrm{T}_{3}$ on cell proliferation was assayed in three HepG2 stable cell lines with high expression of
TR $\alpha 1$ or TR $\beta 1$ as previously described (Lin et al. 2004). Figure 1 shows that without $\mathrm{T}_{3}$ cells proliferated roughly 2 to 3 times faster than those grown in media containing either 10 or $100 \mathrm{nM} \mathrm{T}_{3}$ in three TR stable lines. However, this $\mathrm{T}_{3}$-repressed effect was not observed in the control cell line, HepG2-Neo, which did not express TR (Fig. 1). Following $T_{3}$ treatment, the doubling time for HepG2-TR stable lines increased from $1 \cdot 03 \pm 0 \cdot 12$ to $2 \cdot 49 \pm 0 \cdot 31$ days for TRal\#1 cells, and from $1 \cdot 15 \pm 0 \cdot 21$ to $2 \cdot 64 \pm 0 \cdot 25$ days for TR $\beta 1$ cells; thus $\mathrm{T}_{3}$ repressed the growth of HepG2-TR cells by around 
Table 1 The effect of $\mathrm{T}_{3}$ on cell cycle distribution in HepG2-TR $\alpha 1$, -TR $\beta 1$ and -Neo cells. Data are means \pm S.E.

Cell cycle distribution (\%)

\begin{tabular}{|c|c|c|}
\hline & \\
\hline & G0/G1 & $S$ \\
\hline \multicolumn{3}{|c|}{ HepG2-TR $\alpha 1$} \\
\hline $12 \mathrm{~h}$ & $56 \cdot 56 \pm 1 \cdot 33$ & $29 \cdot 56 \pm 0.45$ \\
\hline $12 \mathrm{~h}+\mathrm{T}_{3}$ & $66 \cdot 77 \pm 1 \cdot 07$ & $18 \cdot 38 \pm 0.51$ \\
\hline $24 \mathrm{~h}$ & $61 \cdot 35 \pm 3.01$ & $30.27 \pm 2.73$ \\
\hline $24 h+T_{3}$ & $83.07 \pm 1.51$ & $8.87 \pm 0.93$ \\
\hline $48 \mathrm{~h}$ & $68 \cdot 30 \pm 1 \cdot 41$ & $25.06 \pm 1.44$ \\
\hline $48 \mathrm{~h}+\mathrm{T}_{3}$ & $91.91 \pm 0.87$ & $4.20 \pm 0.48$ \\
\hline \multicolumn{3}{|c|}{ HepG2-Neo } \\
\hline $12 \mathrm{~h}$ & $63 \cdot 79 \pm 2 \cdot 45$ & $21.55 \pm 0.52$ \\
\hline $12 \mathrm{~h}+\mathrm{T}_{3}$ & $65.56 \pm 2.53$ & $19 \cdot 93 \pm 0 \cdot 12$ \\
\hline $24 \mathrm{~h}$ & $57 \cdot 55 \pm 4 \cdot 37$ & $30 \cdot 49 \pm 3.42$ \\
\hline $24 \mathrm{~h}+\mathrm{T}_{3}$ & $60 \cdot 74 \pm 6 \cdot 62$ & $28.67 \pm 3.29$ \\
\hline $48 \mathrm{~h}$ & $74 \cdot 30 \pm 2 \cdot 61$ & $20 \cdot 40 \pm 1.66$ \\
\hline $48 \mathrm{~h}+\mathrm{T}_{3}$ & $80 \cdot 41 \pm 4.55$ & $15 \cdot 19 \pm 3 \cdot 70$ \\
\hline \multicolumn{3}{|c|}{ HepG2-TRß1 } \\
\hline $12 \mathrm{~h}$ & $51.95 \pm 5.43$ & $33.07 \pm 3.62$ \\
\hline $12 \mathrm{~h}+\mathrm{T}_{3}$ & $62.40 \pm 3.54$ & $18.78 \pm 3.58$ \\
\hline $24 \mathrm{~h}$ & $69 \cdot 13 \pm 4 \cdot 27$ & $25 \cdot 78 \pm 6 \cdot 10$ \\
\hline $24 \mathrm{~h}+\mathrm{T}_{3}$ & $83 \cdot 26 \pm 3 \cdot 82$ & $10 \cdot 90 \pm 2 \cdot 16$ \\
\hline $48 \mathrm{~h}$ & $65.26 \pm 4.91$ & $24.90 \pm 2.56$ \\
\hline $48 \mathrm{~h}+\mathrm{T}_{3}$ & $84.66 \pm 2 \cdot 46$ & $8 \cdot 70 \pm 1 \cdot 46$ \\
\hline
\end{tabular}

two- to three-fold. However, $\mathrm{T}_{3}$ did not influence the doubling time in HepG2-Neo cells (1.58 vs 1.67 days, 0 vs $\left.100 \mathrm{nM} \mathrm{T}_{3}\right)$. All data indicate that $\mathrm{T}_{3}$ significantly suppresses the growth of HepG2-TR but not HepG2-Neo cells.

To identify the phase of the cell cycle affected by $\mathrm{T}_{3}$, cell cycle distribution was assayed via flow cytometry. Table 1 illustrates that the addition of $\mathrm{T}_{3}$ increased the percentage of cells in the G0/G1 phases by roughly $1 \cdot 2-, 1 \cdot 4-$, and 1.35-fold following 12, 24, and $48 \mathrm{~h}$ respectively. Simultaneously with the increase in cell number in the $\mathrm{G} 0 / \mathrm{G} 1$ phases, the percentage of cells in the $\mathrm{S}$ phase was reduced in HepG2-TR $\alpha 1 \# 1$ (Table 1). Similar results occurred in HepG2-TR $\beta 1$ (Table 1) and HepG2-TR $\alpha 1 \# 2$ cells (data not shown).

\section{$T_{3}$ represses the protein expression levels of cdk2 and cyclin $E$}

The major kinase associated with cyclin $\mathrm{E}$ in human cells is cdk2. The formation of the cyclin $\mathrm{E}-\mathrm{cdk} 2$ complex is an important step in the biochemical pathway that controls cell proliferation during G1. Additionally, cyclin $\mathrm{E}$ is one of the key regulators of the G1/S transition in the cell cycle. Over-expression of cyclin $\mathrm{E}$ has been noted in several malignancies and is associated with high cell proliferation (Keyomarsi \& Herliczek 1997, Nielsen et al. 1998). Therefore, this study used western blot analysis to determine that the increase in the G0/G1 cell population was inversely associated with the level of cyclin E-cdk2 proteins. Treatment of HepG2-TR $\alpha 1 \# 1,-T R \alpha 1 \# 2$ and -TR $\beta 1$ cells using $100 \mathrm{nM} \mathrm{T}_{3}$ led to a down-regulation of approximately 32 and $52 \%$ in the level of cdk2 protein following 24, and $48 \mathrm{~h}$ compared with $\mathrm{T}_{3}$-depleted media (Td) in HepG2-TRal\#1 cells (Fig. 2A, B). Similarly, $100 \mathrm{nM} \mathrm{T}_{3}$ led to down-regulation of approximately 27 and $31 \%$ in the protein level of cyclin E following 24 and $48 \mathrm{~h}$ (Fig. 2A, B). A similar effect was observed in the HepG2-TR $\beta 1$ (Fig. 2C), and HepG2TRa1\#2 cell lines (data not shown). Taken together, repression of both components of the cyclin E-cdk2 complex strongly agrees with the previous result of cell cycle blockage in G0/G1.

\section{$\mathrm{T}_{3}$-repressed cell proliferation results from stimulation of p21 expression}

Levels of the negative regulator of cell cycle progression, p21 protein, increase in senescent cells, while p21 over-expression has been demonstrated to block tumor cell growth (Gong et al. 2003). Thus, p21 was investigated as an additional target for controlling cell proliferation. p21 mRNA was strongly induced 1.3-, 3.9and 7·3-fold in HepG2-TR $\alpha 1 \# 1$ cells at 12, 24, and $48 \mathrm{~h}$ respectively, following the addition of $10 \mathrm{nM} \mathrm{T}_{3}$ to the media (Fig. 3A, B). Similarly, p21 protein was also significantly induced two- to five-fold by $\mathrm{T}_{3}$ treatment in two TR $\alpha 1$ stable cell lines (Fig. 3C, D). However, $\mathrm{T}_{3}$ did

Figure 2 Effect of $T_{3}$ on cdk2 and cyclin E protein expression in HepG2-TR cells. (A) TR 1 1\#1 expressing HepG2 stable line was incubated using $\mathrm{T}_{3}$-depleted medium in both the absence or presence of 10 and $100 \mathrm{nM} \mathrm{T}$ for 12,24 , and $48 \mathrm{~h}$, after which cell lysates $(100 \mu \mathrm{g}$ protein) were subjected to immunoblot analysis with cdk2 monoclonal or cyclin $\mathrm{E}$ polyclonal antibodies. The position of the $29 \mathrm{kDa}, 53 \mathrm{kDa}, 43 \mathrm{kDa}$ bands for cdk2, cyclin E, and actin respectively are indicated on the left of each blot. (B) The intensities of each protein band were quantified, and the extent of $T_{3}$-induced change in protein levels was determined at each time point. The results are expressed as percentage expression relative to the control ( $\mathrm{Td}, 0 \mathrm{nM} \mathrm{T}$; open bars) conditions. Data are expressed as means \pm S.E. of values from three independent experiments. ${ }^{*} P<0.05,{ }^{* *} P<0.01, T_{3}$-treated vs Td-treated (Student's $t$-test). Solid bars, $10 \mathrm{mM} \mathrm{T}_{3}$; hatched bars, $100 \mathrm{mM} \mathrm{T}_{3}$. (C) TR $\beta 1$ expressing HepG2 stable line was incubated using $\mathrm{T}_{3}$-depleted medium in both the absence or presence of 10 and $100 \mathrm{nM} \mathrm{T}$ for 12,24 , and $48 \mathrm{~h}$, after which cell lysates (100 $\mu \mathrm{g}$ protein) were subjected to immunoblot analysis with cdk2 monoclonal or cyclin E polyclonal antibodies. The position of the $29 \mathrm{kDa}, 53 \mathrm{kDa}$, $43 \mathrm{kDa}$ bands for cdk2, cyclin E, and actin respectively are indicated on the left of each blot. 
(A)

HepG2-TR $\alpha 1 \# 1$

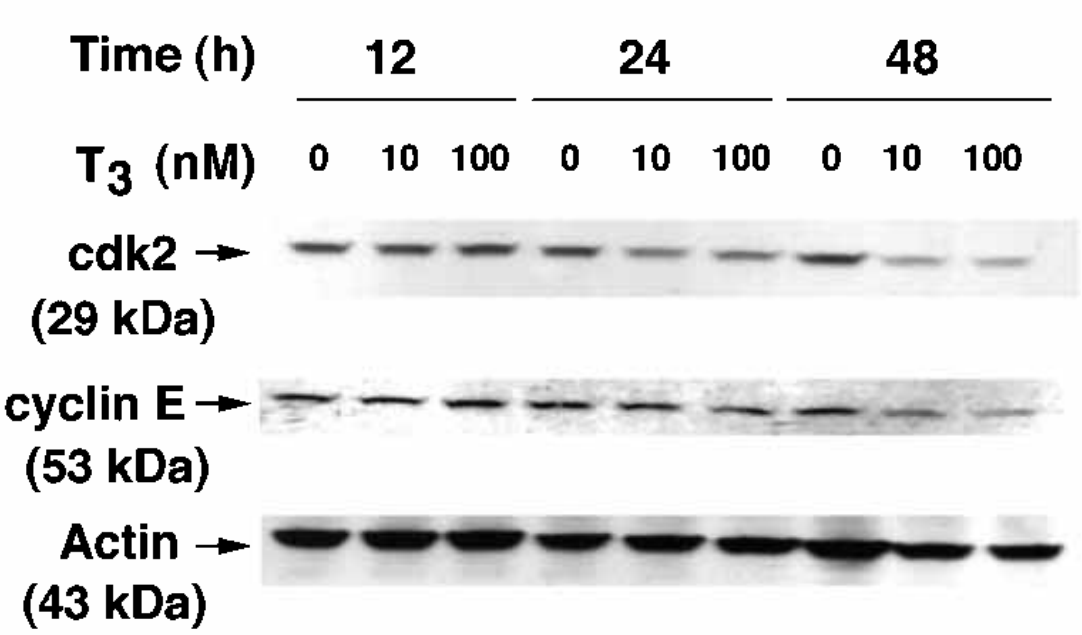

(B)

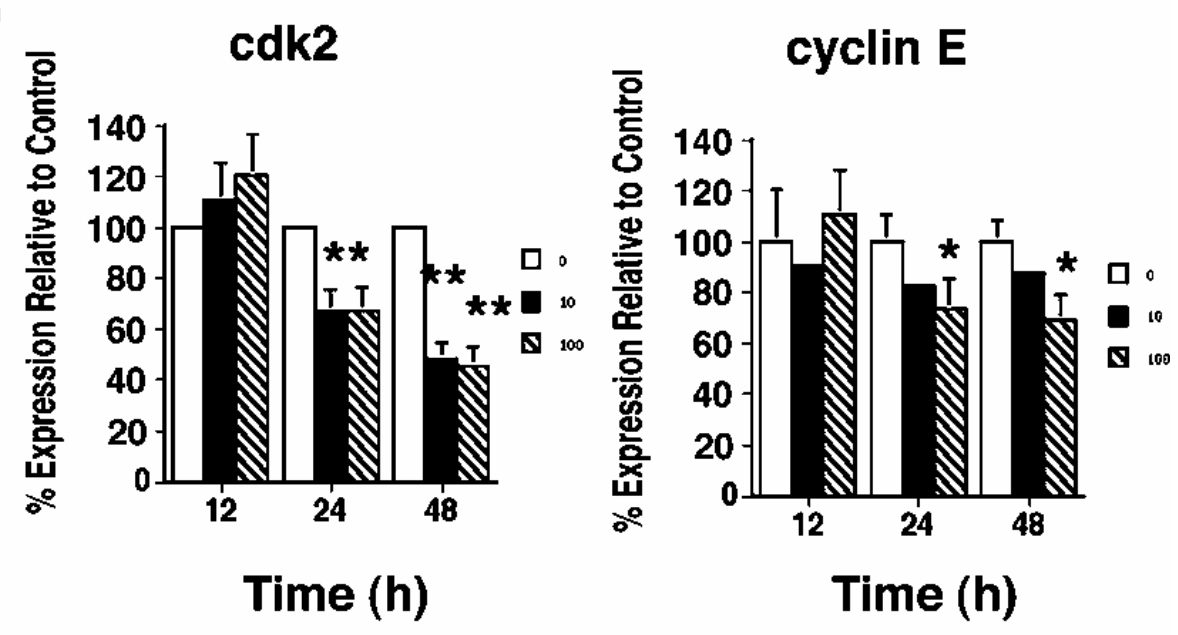

(C) HepG2-TR $\beta 1$

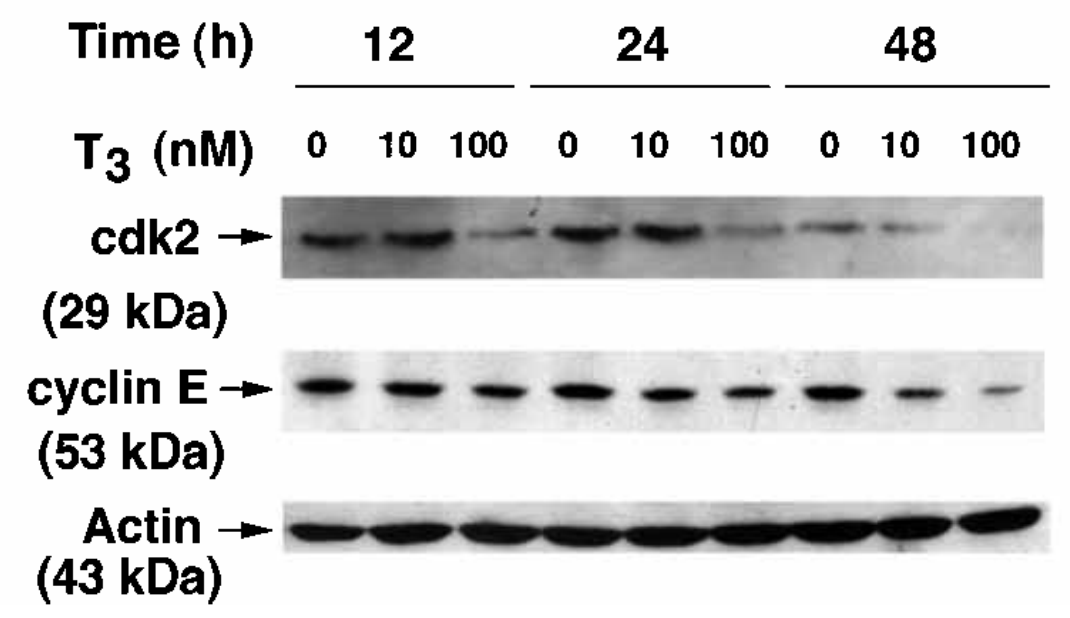


(A) HepG2-TR $\alpha 1 \# 1$
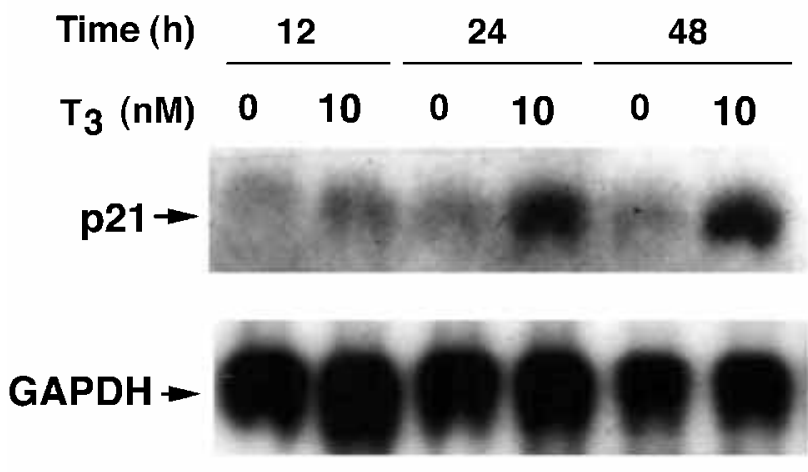

(B)

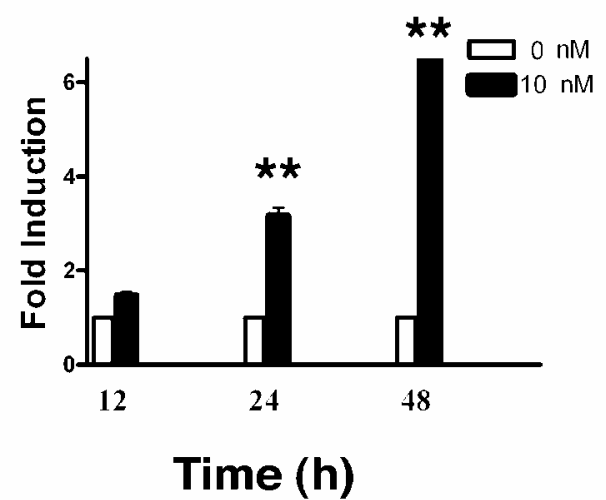

(C) HepG2-TR $\alpha 1 \# 1$

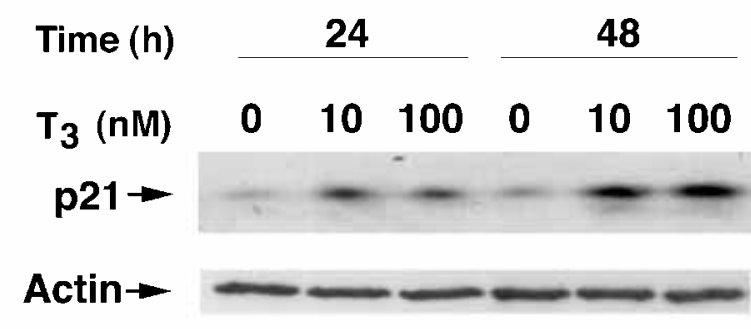

HepG2-TR $\alpha 1 \# 2$
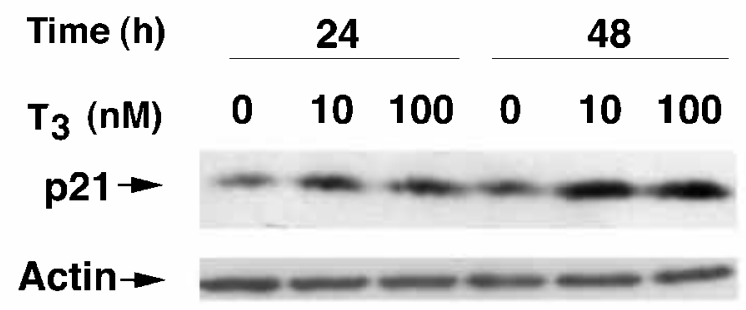

(D)

\#1

\#2
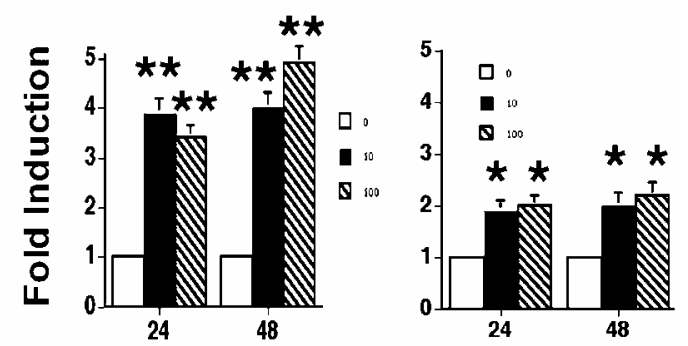

Time (h)

Figure 3 Influence of $T_{3}$ on p21 expression in HepG2-TR $\alpha 1$ cells at the mRNA and protein levels. (A) HepG2-TR $1 \# 1$ cells were incubated for 12, 24 or $48 \mathrm{~h}$ with or without $10 \mathrm{nM} \mathrm{T}$, after which total RNA was isolated and subjected (20 $\mu \mathrm{g}$ per lane) to Northern blot analysis with ${ }^{32}$-labeled p21 or GAPDH cDNA probes. The positions of the 2.3-kb p21 and 1.0-kb GAPDH mRNAs are indicated. (B) The intensities of the p21 mRNA bands on blots similar to that shown in (A) were quantified, and the extent of the $T_{3}$-induced increase in the abundance of p21 transcripts was determined at each point. Data are means $\pm S$.E. of values from three independent experiments. ${ }^{* *} P<0.01, \mathrm{~T}_{3}$-ttreated vs Td-treated (Student's $t$-test). (C) HepG2-TR $\alpha$ 1\#1 and HepG2-TR $\alpha$ 1\#2 cells were incubated for 24 or $48 \mathrm{~h}$ with and without 10 or $100 \mathrm{nM} \mathrm{T}_{3}$, after which total protein was isolated and subjected to Western blot analysis. (D) The intensities of the p21 protein bands on blots similar to that shown in (C) were quantified using the two stable lines. Data are means \pm S.E. of values from three independent experiments. ${ }^{*} P<0.05,{ }^{* *} P<0.01, T_{3}$-treated vs Td-treated (Student's $t$-test). Open bars, $0 \mathrm{nM} \mathrm{T}_{3}$; solid bars, $10 \mathrm{nM} \mathrm{T}_{3}$; hatched bars, $100 \mathrm{nM} \mathrm{T}_{3}$.

not markedly increase p21 mRNA or protein expression in the control cell line, HepG2-Neo (data not shown).

\section{$\mathrm{T}_{3}$ treatment impacts the phosphorylation state of Rb protein}

$\mathrm{Rb}$ tumor suppressor is a critical negative regulator of cellular proliferation. The $\mathrm{Rb}$ protein was dephosphorylated (Fig. 4A) in HepG2-TRal\#1 or two other TR stable cell lines (data not shown) following $\mathrm{T}_{3}$ addition, possibly indicating that cyclin $\mathrm{E}$ was inactivated by $\mathrm{p} 21$. The expression of hyperphosphorylated $\mathrm{Rb}$ protein increased significantly following 24 or $48 \mathrm{~h}$ $\mathrm{T}_{3}$ treatment when HepG2-TR $\alpha 1$ cells were incubated in control conditions (Td) (Fig. 4A). As a further positive control, the phosphorylation status of $\mathrm{Rb}$ was investigated in the GC cell line. Consistent with previous studies (Barrera-Hernandez et al. 1999), $\mathrm{Rb}$ was 


\section{(A) HepG2-TR $\alpha 1 \# 1$}
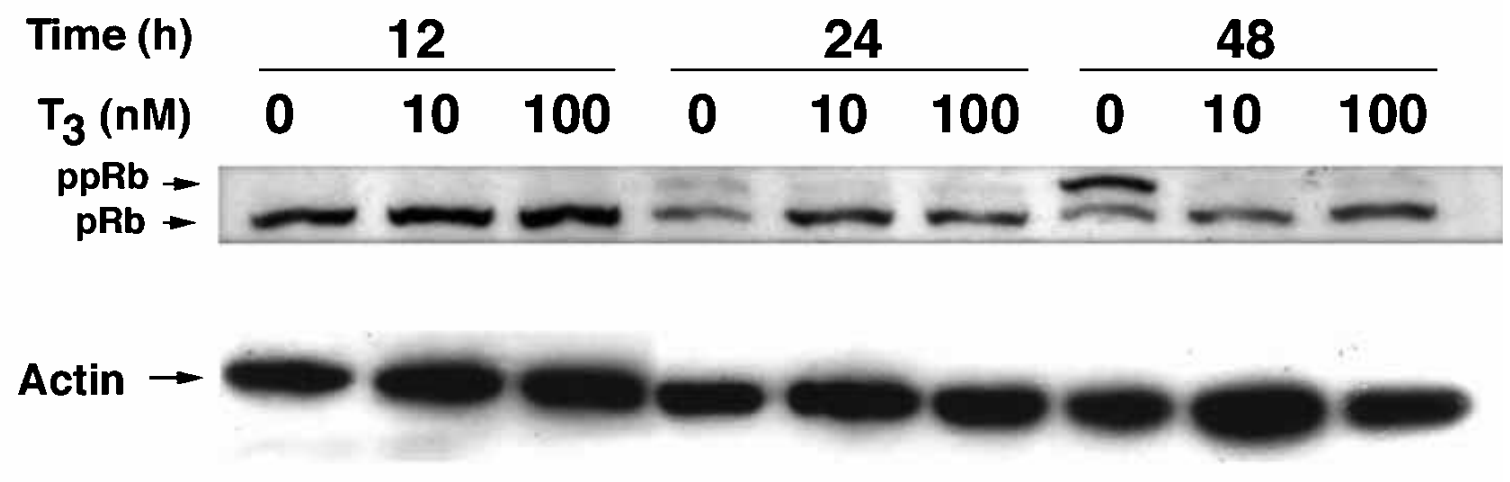

\section{(B) GC}
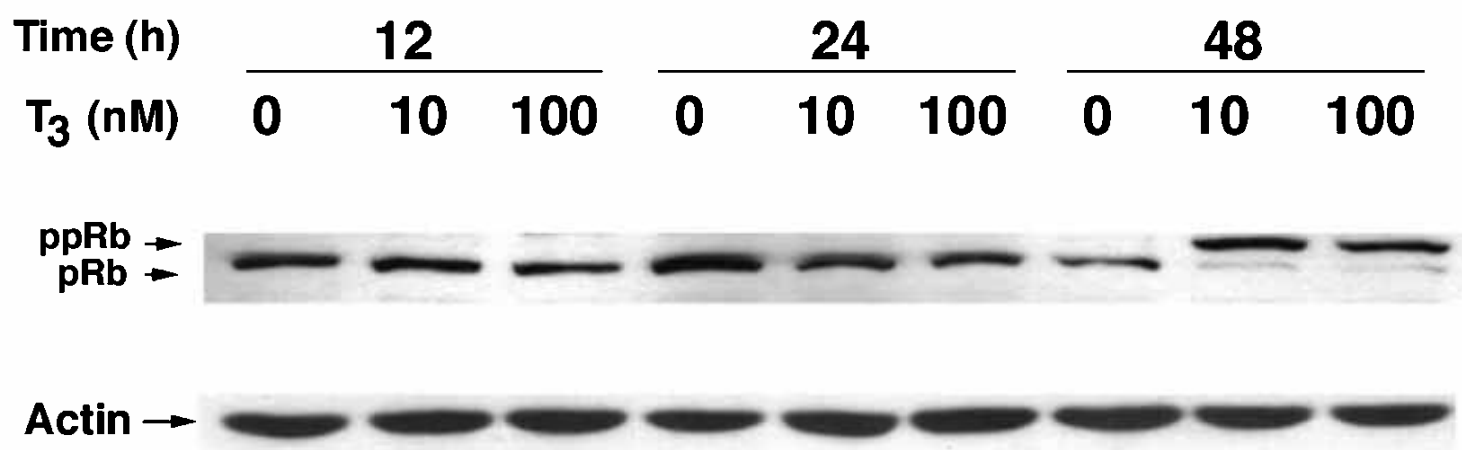

Figure 4 Influence of $T_{3}$ on Rb protein in HepG2-TR $\alpha 1$ and GC cells. (A) TR $\alpha 1$ expressing HepG2 stable line or (B) GC cells were incubated with $\mathrm{T}_{3}$-depleted medium with or without 10 or $100 \mathrm{nM} \mathrm{T}$ for 12,24 , and $48 \mathrm{~h}$, after which cell lysates (100 $\mu$ g protein) were subjected to immunoblot analysis with polyclonal antibodies to Rb. The arrows indicate the hyperphosphorylated (ppRb) and hypophosphorylated $(\mathrm{pRb})$ forms of Rb. Actin served as an internal control. Data were obtained from three independent experiments.

hyperphosphorylated in GC cells after $\mathrm{T}_{3}$ treatment for $48 \mathrm{~h}$ (Fig. 4B). However, $\mathrm{T}_{3}$ did not significantly change the phosphorylation status of $\mathrm{Rb}$ in the control cell line, HepG2-Neo (data not shown). These experimental results indicate that the incubation of HepG2 cells over-expressing $\mathrm{TR}$ in media containing $\mathrm{T}_{3}$ represses the hyperphosphorylation of $\mathrm{Rb}$.

\section{TGF- $\beta$ is stimulated by $T_{3}$}

To better understand how $\mathrm{T}_{3}$ inhibited the proliferation of HepG2-TR $\alpha 1$ cells, this study investigated the influence of $\mathrm{T}_{3}$ on the TGF- $\beta$ expression. Similar to previously published results (Lin et al. 2004), TGF- $\beta$ at the mRNA level was significantly stimulated about $1 \cdot 5$ to 3-fold by $\mathrm{T}_{3}$ in HepG2-TRa1\#1 cells (Fig. 5A). Additionally, the $12 \mathrm{kDa}$ TGF- $\beta$ protein was upregulated about two- to threefold 24 or $48 \mathrm{~h}$ following the addition of $\mathrm{T}_{3}$ (Fig. 5B). To further clarify the influence of $\mathrm{T}_{3}$ on TGF- $\beta$ at the transcriptional level, the TGF- $\beta$ 5'-flanking region (from -1362 to +101 ) was cloned into the pGL3 vector and its activity was assayed. $\mathrm{T}_{3}$ was demonstrated to increase the promoter activity by approximately $7 \cdot 8$ - and $5 \cdot 8$-fold at 10 and $100 \mathrm{nM}$ concentrations of $T_{3}$ respectively in the TR $\alpha 1$ stable cell line, compared with its activity in control $(\mathrm{Td})$ media without the addition of $\mathrm{T}_{3}$ (Fig. $5 \mathrm{C}$ ). However, $\mathrm{T}_{3}$ did not considerably increase the promoter activity in the control cell line, HepG2-Neo (Fig. 5C).

\section{TGF- $\beta$ and its neutralizing antibody influence cyclin $\mathrm{E}, \mathrm{cdk2}$ and $\mathrm{Rb}$ expression}

To clarify the signaling pathways involved in the repression of cyclin $\mathrm{E}, \operatorname{cdk} 2$ and $\mathrm{Rb}$ by $\mathrm{T}_{3}$, this study investigated the involvement of TGF- $\beta$. The data indicate that treating cells with $\mathrm{T}_{3}$ for $48 \mathrm{~h}$ represses cdk2 expression by at least $40 \%$ at the protein level compared with the control $(\mathrm{Td})$ conditions (Fig. 2A, B; Fig. $6 \mathrm{~A}, \mathrm{~B}, \mathrm{C}$, lane 1 vs 2). Moreover, TGF- $\beta$ alone also 

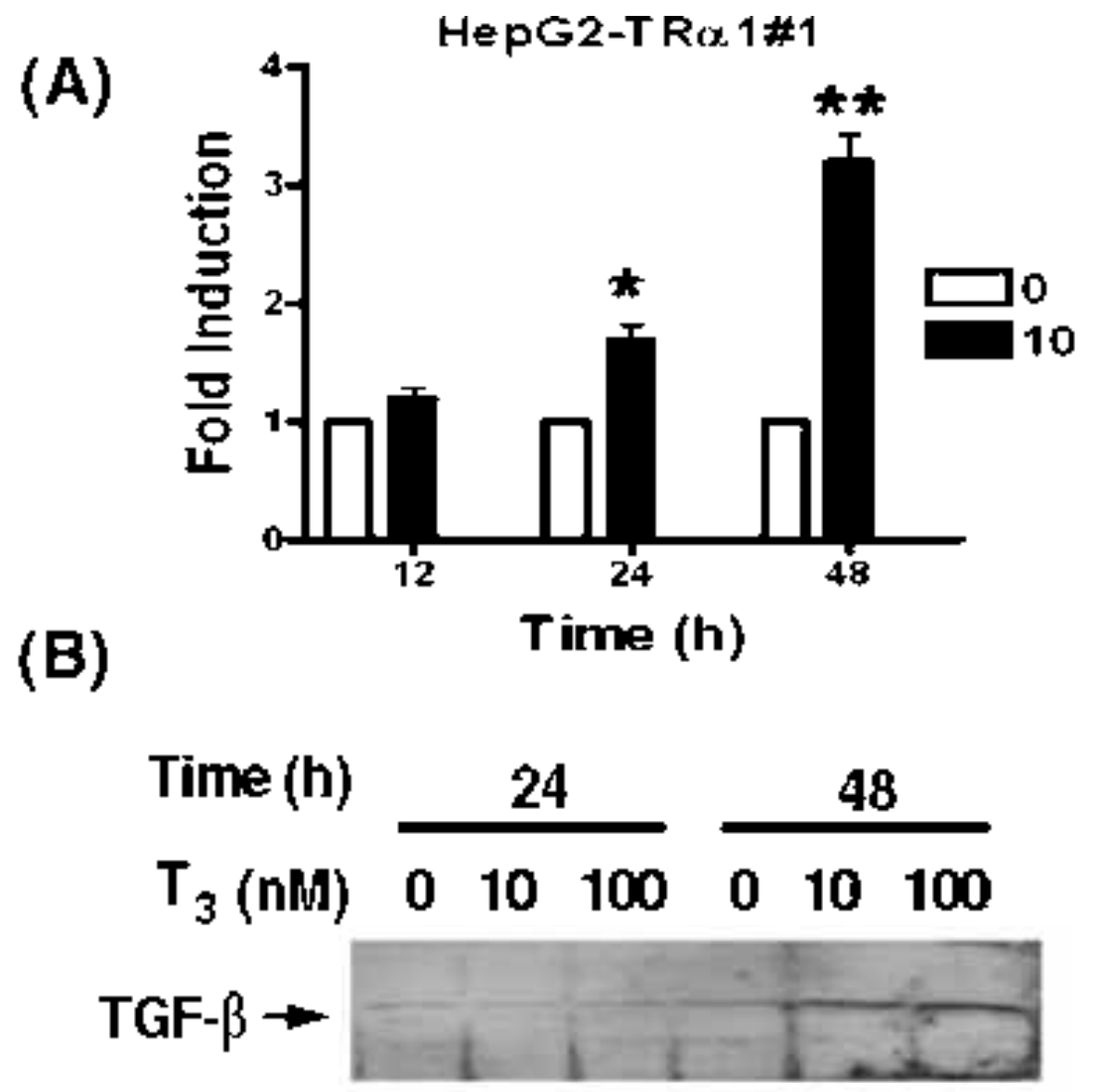

\section{Actin -}

(C)

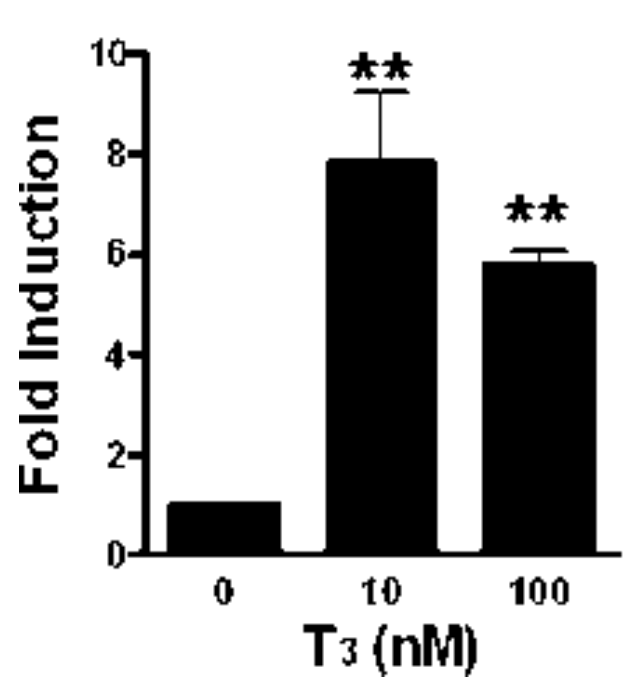

HepG2-Neo

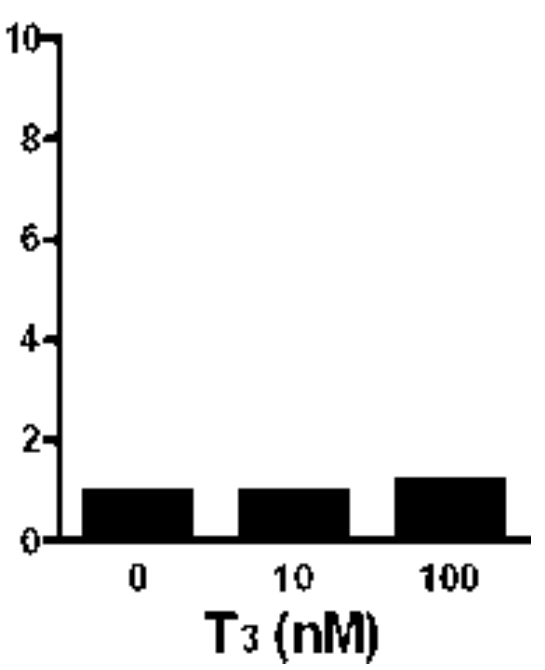


repressed the expression of cdk2 following $40 \mathrm{~min}$ treatment (Fig. 6A, B, C lane 1 vs 3). Notably, either $\mathrm{T}_{3}$ or TGF- $\beta$ repressed the expression of cyclin E, cdk2, and rendered the $\mathrm{Rb}$ protein in the hypophosphorylated form (Fig. 6A, B, G lane 1 vs 2 and 3) in the HepG2-TR cells. Importantly, the repression of cyclin E, cdk2, and ppRb by $\mathrm{T}_{3}$ was blocked by the addition of TGF- $\beta$ neutralizing antibody (nAb) (Fig. 6A, B, C lane 2 vs 6), but not by the non-specific antibody (nsAb) (Fig. 6A, B, $\mathrm{C}$, lane 2 vs 5) in the HepG2-TR $\alpha 1 \# 1$, -TR $\alpha 1 \# 2$, and $-T R \beta 1$ stable lines. However, the effects of $\mathrm{T}_{3}$ and TGF- $\beta$ were not observed in the Neo cells (Fig. 6D) and did not synergistically repress the expression of cyclin $\mathrm{E}$, cdk2, and ppRb (Fig. 6A, B, C lane 4 vs 2 and 3 ) in the HepG2-TR cells. Moreover, TGF- $\beta$ neutralizing antibody, but not the control antibody can reverse the cell growth inhibition effect of $\mathrm{T}_{3}$ (Fig. 1). Thus, cell proliferation is repressed by $\mathrm{T}_{3}$ through a TGF- $\beta$ mediated mechanism. Additionally, $\mathrm{T}_{3}$ controls the expression and activity of a number of cell cycle regulators via TGF- $\beta$, including $\mathrm{p} 21, \mathrm{pRb}$ and the cyclin E-cdk2 complex.

\section{Discussion}

This study identified a novel pathway of $\mathrm{T}_{3}$ signaling mediated by TGF- $\beta$ for inhibiting the proliferation of hepatoma cells expressing high levels of TR proteins. The effect of $\mathrm{T}_{3}$ treatment in promoting the proliferation of normal hepatocyes or GC cells derived from the pituitary has been well documented (Chou et al. 1987, Barrera-Hernandez et al. 1999). However, HepG2 and Hep3B cells do not express detectable TR proteins (Lin et al. 1994). Unlike previous studies, the results of this study indicate that $\mathrm{T}_{3}$ represses the proliferation of hepatoma cells rather than promoting it. The experimental data indicate that $T_{3}$ only significantly suppresses the growth of HepG2-TR over-expressing cells. However, this $\mathrm{T}_{3}$-repressed effect was not observed in the control cell line (HepG2-Neo) that did not express detectable TR. The study does not contradict the results of in vivo studies reported by Ledda-Columbano et al. (2000). Their results demonstrated that $\mathrm{T}_{3}$ supplemented an increase in the BrdUrd-labeling index in the carcinogen-induced rat hepatocellular carcinoma (HCC). However, the TR expressing level in rat HCG is unknown (Ledda-Columbano et al. 2000). Actually, their data indicated that $\mathrm{T}_{3}$ administration, despite stimulating hepatocyte proliferation, resulted in a $70 \%$ reduction in the number of glutathione S-transferase (GST)positive lesions, the marker enzyme used to identify pre-neoplastic lesion, with no increase in the size of the remaining nodules. In addition, repeated exposure of nodule-bearing rats to $\mathrm{T}_{3}$ caused a $50 \%$ reduction in the incidence of HCGs and $100 \%$ inhibition of lung metastasis. Their data also support the concept that $\mathrm{T}_{3}$-induced cell proliferation might not necessarily represent a promoting condition for putative preneoplastic lesions and demonstrates an anticarcinogenic effect of $T_{3}$. To confirm that the suppressive effect of $T_{3}$ treatments on hepatoma cell proliferation did not simply result from the toxic effects of this hormone, this study examined the expression of a number of factors that are known to be significantly involved in the cell cycle, for example cdk2, Rb, p21 and cyclin E. Additionally, this work used the GC cell line, which is known to proliferate when stimulated by $\mathrm{T}_{3}$ (Barrera-Hernandez et al. 1999). This study found that $\mathrm{T}_{3}$ repressed hepatoma cell growth by lengthening the G1 phase of the cell cycle, concomitantly decreasing the expression of $\mathrm{cdk} 2$ and cyclin E. To study the expression kinetics of the cell cycle, several regulatory factors were assayed, including proliferation cell nuclear antigen (PGNA), which represents an endogenous protein of the DNA polymerase $\delta$. PGNA is an essential auxiliary protein of DNA polymerase $\delta$, and is synthesized in the early G1 and $\mathrm{S}$ phases for processing of DNA replication. PGNA mRNA was repressed following $\mathrm{T}_{3}$ treatment in HepG2-TR stable lines (data not shown). This provides further support for the notion that $\mathrm{T}_{3}$ can suppress proliferation in cells that express TR.

cdk2 has been demonstrated to play a pivotal role in regulating cell cycle progression, is regulated by phosphorylation and can associate with cyclins A, E, D1, and D3. This investigation found that the inhibitory effect of $\mathrm{T}_{3}$ on cell proliferation occurs during the G0/G1 phase of the cell cycle. Interestingly, the

\footnotetext{
Figure 5 Induction of TGF- $\beta$ by $\mathrm{T}_{3}$ in HepG2-TR $\alpha 1$ cells. (A) HepG2-TR $\alpha 1$ cells were incubated using $\mathrm{T}_{3}$-depleted medium with or without $10 \mathrm{nM} \mathrm{T}_{3}$ for 12 to $48 \mathrm{~h}$, after which total RNA was isolated and subjected to Q-RT-PCR for TGF- $\beta$ expression as described in the Materials and methods section. Results are expressed as fold induction by $T_{3}$. Data are means $\pm S$.E. of values from three independent experiments. ${ }^{*} P<0.05$, ${ }^{* *} P<0.01, \mathrm{~T}_{3}$-treated vs Td-treated (Student's $t$-test). (B) Immunoblot analysis of TGF- $\beta$ in HepG2-TR $\alpha 1 \# 1$ cell lines. Lysates (100 $\mu$ g protein) from HepG2-TR $\alpha 1$ cells were subjected to immunoblot analysis with monoclonal antibody to TGF- $\beta$ as described in the Materials and methods section. The position of the 12-kDa TGF- $\beta$ is indicated. Actin served as an internal control. (C) $\mathrm{T}_{3}$-dependent trans-activity of TR $\alpha 1$ and Neo control cells in TGF- $\beta$ promoter. Cells were transfected using a luciferase reporter plasmid containing the TGF- $\beta$ 5'-flanking region encompassing nucleotides $-1362 /+101$ (Kim et al. 1989a) and with a $\beta$-galactosidase plasmid to control for transfection efficiency. Subsequent procedures are described in the Materials and methods section. Data were obtained from three independent experiments, each performed in duplicate. The ordinate indicates 'Fold induction' and non-induced $=1 .{ }^{* *}, P<0.01, \mathrm{~T}_{3}$-treated vs Td-treated (Student's $t$-test). Open bars, $0 \mathrm{nM} \mathrm{T}_{3}$; solid bars, $10 \mathrm{nM} \mathrm{T}_{3}$; hatched bars, $100 \mathrm{nM} \mathrm{T}_{3}$.
} 
(A) HepG2-TR $\alpha 1 \# 1$

$\begin{array}{lcccccc}\mathrm{T}_{3}(\mathrm{nM}) & 0 & 10 & 0 & 10 & 10 & 10 \\ \text { TGF- } \beta & - & - & + & + & - & - \\ \text { nAb } & - & - & - & - & - & + \\ \text { nsAb } & - & - & - & - & + & -\end{array}$

Cycline $\rightarrow$

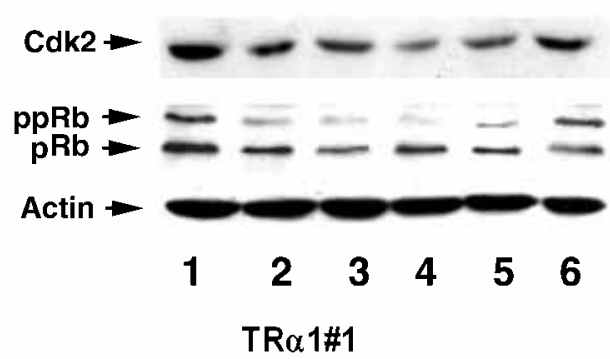

(C) HepG2-TR $\beta 1$

$\begin{array}{lcccccc}\mathrm{T}_{3}(\mathrm{nM}) & 0 & 10 & 0 & 10 & 10 & 10 \\ \text { TGF- } \beta & - & - & + & + & - & - \\ \text { nAb } & - & - & - & - & - & + \\ \text { nsAb } & - & - & - & - & + & -\end{array}$

CyclinE $\rightarrow$
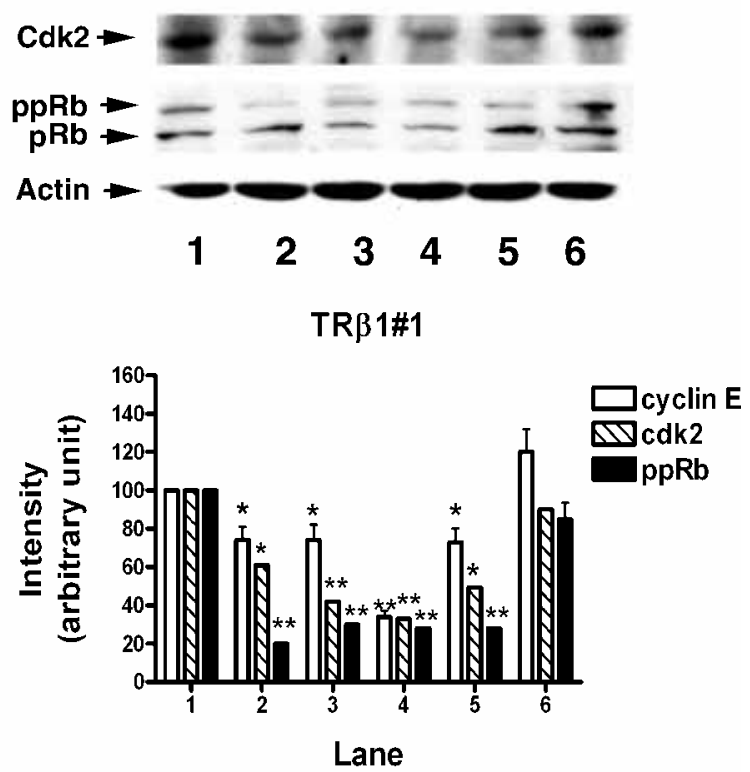

(D) HepG2-Neo

(B) HepG2-TR $\alpha 1 \# 2$

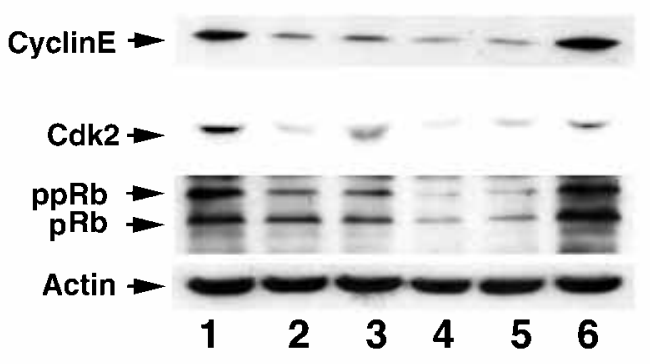

TR $\alpha 1 \# 2$

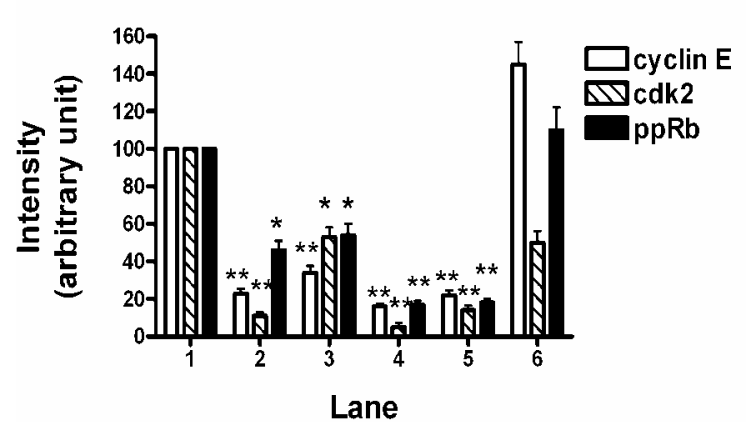

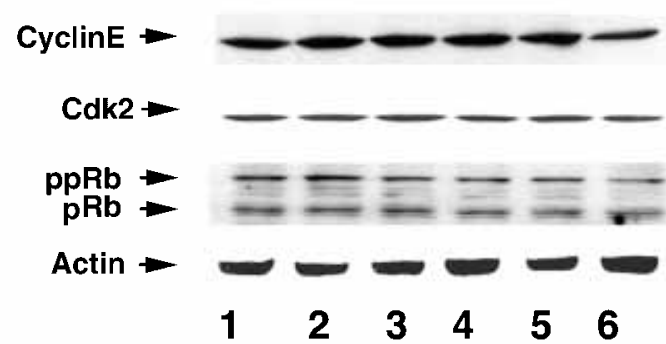

Neo

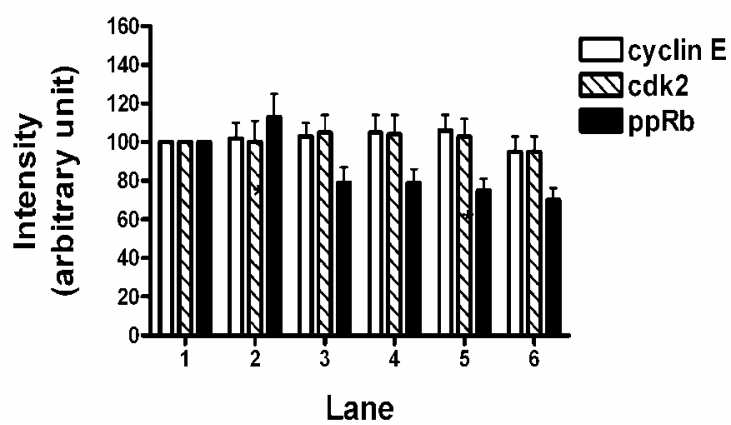


cdk2-cyclinE complex is active in the $\mathrm{Gl}$ and $\mathrm{S}$ phases and is important for the progression from G1 to $\mathrm{S}$ (Harwell et al. 2004, Lents \& Baldassare 2004). Additionally, cyclin $\mathrm{E}$ is pivotal in regulating the restriction point transition in the cell cycle. The role of cyclin $\mathrm{E}$ as a cdk2 activator in controlling restriction point transition in the cell cycle makes cyclin $\mathrm{E}$ an excellent candidate as a factor for involvement in tumor development. The hepatoma cell system presented here demonstrated reduced expression of both cyclin $\mathrm{E}$ and cdk2 following $\mathrm{T}_{3}$ application, although further study is required to determine whether this phenomenon is because of a direct or an indirect effect. Aberrant regulation of cyclin $\mathrm{E}$ is a common phenomenon seen in tumor cells and has been reported in tumor tissues isolated from breast cancer patients (Akli et al. 2004, Harwell et al. 2004). An interesting study by Pibiri et al. (2001) demonstrated that, in Wistar rats, hepatocyte proliferation induced by $\mathrm{T}_{3}$ occurred in the absence of AP-1, nuclear factor- $\kappa \mathrm{B}$, and STAT3 activation or any change in the mRNA levels of the immediate early genes $c$-fos, c-jun, and $c-m y c$. However, this study found that $\mathrm{T}_{3}$ treatment increased cyclin $\mathrm{D} 1 \mathrm{mRNA}$ and protein levels, and moreover this increase occurred much more rapidly than liver regeneration following a two-thirds partial hepatectomy. Regrettably, the expression level of TGF- $\beta$ was not examined. In contrast, in this investigation, we did not observe any significant change in the level of cyclin Dl expression following $\mathrm{T}_{3}$ treatment (data not shown). It is possible that $\mathrm{T}_{3}$ influences the late G1 but not the early G1 phase. The cyclin D1-cdk4, cdk-6 complexes are activated in early G1, whereas cyclin E-cdk2 is activated in late G1 (Sherr 1996, Martin-Castellanos \& Moreno 1997). Therefore, our observations regarding hepatoma cells differ from those for normal regenerating rat liver cells. Summarizing the results of this and previous studies, $\mathrm{T}_{3}$ appears both to induce proliferation of normal hepatocytes and to suppress the proliferation of hepatoma cells with TR expression.

p21 can bind and inhibit each member of the cdk family. It also directly binds to PCNA and thus inhibits DNA replication. The present work showed that the expression of $\mathrm{p} 21$ was stimulated markedly by $\mathrm{T}_{3}$ at both the mRNA and protein levels, and may be, at least partially, responsible for blocking cell proliferation.
TGF- $\beta$ is a pleiotropic cytokine that elicits a broad range of cellular responses, including cell growth, differentiation, and apoptosis. One of the biological effects of TGF- $\beta$ is to inhibit epithelial cell proliferation by inducing cell cycle arrest (Sporn \& Roberts 1992, Massague 1998). The effectors of TGF- $\beta$-induced cell growth inhibition are cyclin-dependent kinase inhibitors; among these inhibitors, p21 Cip1 plays a major role in numerous biological contexts (Li et al. 1995). Additionally, Buzzard et al. (2003) demonstrated that $\mathrm{T}_{3}$ and other hormones induced the progressive accumulation of the cell cycle inhibitors p27 $7^{\mathrm{Kip} 1}$ and $\mathrm{p} 21^{\mathrm{Cip} 1}$ in Sertoli cells. However, the underlying mechanisms responsible for suppressing proliferation remain largely unknown (Gong et al. 2003). This study found that $\mathrm{T}_{3}$ acted on the TGF- $\beta$ promoter to activate transcription. However, further work is required to determine whether this activation is due of a direct or an indirect effect. Therefore, in these hepatoma cells, the two signaling pathways are linked and TGF- $\beta$ works downstream of the $\mathrm{T}_{3}$ pathway.

$\mathrm{Rb}$ is a nuclear phosphoprotein that undergoes differential phosphorylation during the cell cycle. Hypophosphorylated $\mathrm{Rb}$ protein complexes with $\mathrm{E} 2 \mathrm{~F}$ to inhibit its trans-activity on target genes and thus halts cell cycle progression. Barrera-Hernandez et al. (1999) reported that $\mathrm{T}_{3}$ increased the phosphorylation of $\mathrm{Rb}$ protein and thus stimulated GC cell line proliferation, similar to the results obtained here using these cells. By contrast, in this study $\mathrm{T}_{3}$ caused the accumulation of hypophosphorylated $\mathrm{Rb}$ protein, thus suppressing cell cycle progression in hepatoma cells overexpressing TR proteins.

Shimizu et al. (2004) reported that OSI-461 (a potent protein kinase $\mathrm{G}$ activator) enhanced the G0/G1 arrest resulting from acyclic retinoid (belonging to the thyroid/steroid super-family), and a combination of these agents synergistically decreased expression of cyclin D1 protein and mRNA, inhibited cyclin D1 promoter activity, reduced the level of hyperphosphorylated forms of the $\mathrm{Rb}$ protein and induced cellular levels of the p21 Cip1 protein and mRNA in HepG2 cells. These observations mirror some of the results reported here.

Sumitani et al. (1994) reported that androgen significantly stimulates growth of the mouse mammary

Figure $6 T_{3}$, TGF- $\beta$ and its neutralizing antibody influence cyclin E, cdk2, and Rb expression. (A) HepG2-TR $\alpha$ 1\#1, (B)

HepG2-TR $\alpha 1 \# 2$, (C) HepG2-TR $\beta 1$ and (D) HepG2-Neo stable lines were incubated using $T_{3}$-depleted medium with or without $10 \mathrm{nM} \mathrm{T}_{3}$ for $48 \mathrm{~h}$, after which cell lysates (100 $\mu \mathrm{g}$ protein) were subjected to immunoblot analysis using antibodies against cyclin $\mathrm{E}$, cdk2, and Rb. In lanes 3 and 4 , the final 40 min before the cells were harvested, 5 nM TGF- $\beta 1$ were added. Cells were incubated simultaneously with $\mathrm{T}_{3}$ and $800 \mathrm{ng}$ of the TGF- $\beta$ neutralizing antibody (nAb), lane 6 , or non-specific control antibody (nsAb), lane 5 . Subsequently, cell lysates (100 $\mu \mathrm{g}$ protein) were subjected to immunoblot analysis. The intensities of the cyclin $\mathrm{E}$ (open bars), cdk2 (hatched bars), and ppRb (solid bars) protein bands on the blots were quantified. The data are intensities of lanes 2 to 6 compared with those in lane 1 ( $\mathrm{Td}$ condition) and were from three independent experiments. Actin was used as an internal control. The ordinate indicates 'intensity' and non-induced $(\mathrm{Td})=100$. ${ }^{\star} P<0.05$, ${ }^{\star *} P<0.01$, lanes 2 to 6 vs lane 1 (Student's $t$-test). 
Shionogi carcinoma SC-3 cells. This androgen-induced growth is partially blocked by $\mathrm{T}_{3}$. TGF- $\beta$ also inhibits SC-3 cell growth. Thus, they investigated whether $\mathrm{T}_{3}$ exerted its inhibitory effects on SC-3 cell growth through TGF- $\beta$ mRNA expression. This study showed that $\mathrm{T}_{3}$ stimulated the expression of TGF- $\beta$ at the mRNA and protein levels in HepG2-TR stable cells. Meanwhile, TGF- $\beta 1$ exerted its inhibitory effects through downregulation of PCNA, cdks, and cyclin E. Although this study did not demonstrate the effect of TGF- $\beta$ neutralizing antibody on the growth of HepG2 cells, it did show that TGF- $\beta$ antibody neutralizing $\mathrm{T}_{3}$ repressed cdk2.

In conclusion, this work provides evidence that $T_{3}$ and its receptor mediates the suppression of hepatoma cell proliferation by TGF- $\beta$. The results presented here raise the possibility that $T_{3}$, via its receptors and TGF- $\beta$, helps to regulate hepatocyte tumor growth and development.

\section{Acknowledgements}

This work was supported by grants from Chang-Gung University, Taoyuan, Taiwan (CMRP 1332, NMRP 1074) and the National Science Council of the Republic of China (NSC 91-2320-B-182-041). The authors declare that there is no conflict of interest that would prejudice the impartiality of this scientific work.

\section{References}

Akli S, Zheng PJ, Multani AS, Wingate HF, Pathak S, Zhang N, Tucker SL, Chang S \& Keyomarsi K 2004 Tumor-specific low molecular weight forms of cyclin E induce genomic instability and resistance to p21, p27, and antiestrogens in breast cancer. Cancer Research 64 3198-3208.

Alisi A, Spagnuolo S, Napoletano S, Spaziani A \& Leoni S 2004 Thyroid hormones regulate DNA-synthesis and cell-cycle proteins by activation of PKCalpha and p42/44 MAPK in chick embryo hepatocytes. Fournal of Cellular Physiology 201 259-265.

Aranda A \& Pascual A 2001 Nuclear hormone receptors and gene expression. Physiological Reviewes 81 1269-1304.

Barrera-Hernandez G, Park KS, Dace A, Zhan Q \& Cheng SY 1999 Thyroid hormone-induced cell proliferation in GC cells is mediated by changes in G1 cyclin/cyclin-dependent kinase levels and activity. Endocrinology $1405267-5274$.

Buzzard JJ, Wreford NG \& Morrison JR 2003 Thyroid hormone, retinoic acid, and testosterone suppress proliferation and induce markers of differentiation in cultured rat sertoli cells. Endocrinology $1443722-3731$.

Chamba A, Neuberger J, Strain A, Hopkins J, Sheppard MC \& Franklyn JA 1996 Expression and function of thyroid hormone receptor variants in normal and chronically diseased human liver. Fournal of Clinical Endocrinology and Metabolism 81 360-367.

Chang C, Lin Y, Ol TW, Chou CK, Lee TS, Liu TJ, P'eng FK, Chen TY \& Hu CP 1983 Induction of plasma protein secretion in a newly established human hepatoma cell line. Molecular and Cellular Biology 3 1133-1137.
Cheng SY 2000 Multiple mechanisms for regulation of the transcriptional activity of thyroid hormone receptors. Revieres in Endocrine and Metabolic Disorders 1 9-18.

Chou CK, Ho LT, Ting LP, Hu CP, Su TS, Chang WC, Suen CS, Huang MY \& Chang CM 1987 Selective suppression of insulin-induced proliferation of cultured human hepatoma cells by somatostatin. Fournal of Clinical Investigation 79 175-178.

De Caestecker M 2004 The transforming growth factor-beta superfamily of receptors. Cytokine and Growth Factor Reviews $\mathbf{1 5}$ $1-11$.

Fan XG, Fan XJ, Xia HX, Keeling PW \& Kelleher D 1995 Up-regulation of CD44 and ICAM-1 expression on gastric epithelial cells by H. pylori. APMIS: Acta Pathologica, Microbiologica et Immunologica Scandinavica 103 744-748.

Gong J, Ammanamanchi S, Ko TC \& Brattain MG 2003 Transforming growth factor beta 1 increases the stability of p21/WAF1/CIP1 protein and inhibits CDK2 kinase activity in human colon carcinoma FET cells. Cancer Research 63 3340-3346.

Harwell RM, Mull BB, Porter DC \& Keyomarsi K 2004 Activation of cyclin-dependent kinase 2 by full length and low molecular weight forms of cyclin $\mathrm{E}$ in breast cancer cells. Fournal of Biological Chemistry 279 12695-12705.

Hulbert AJ 2000 Thyroid hormones and their effects: a new perspective. Biological Reviews of the Cambridge Philosophical Society 75 519-631.

Keyomarsi K \& Herliczek TW 1997 The role of cyclin E in cell proliferation, development and cancer. Progress in Cell Cycle Research 3 171-191.

Kim SJ, Glick A, Sporn MB \& Roberts AB 1989a Characterization of the promoter region of the human transforming growth factor-beta 1 gene. Fournal of Biological Chemistry 264 402-408.

Kim SJ, Jeang KT, Glick AB, Sporn MB \& Roberts AB 1989b Promoter sequences of the human transforming growth factor-beta 1 gene responsive to transforming growth factor-beta 1 autoinduction. Fournal of Biological Chemistry 264 7041-7045.

Ledda-Columbano GM, Perra A, Loi R, Shinozuka H \& Columbano A 2000 Cell proliferation induced by triiodothyronine in rat liver is associated with nodule regression and reduction of hepatocellular carcinomas. Cancer Research 60 603-609.

Lents NH \& Baldassare JJ 2004 CDK2 and cyclin E knockout mice: lessons from breast cancer. Trends in Endocrinology and Metabolism $\mathbf{1 5}$ $1-3$.

Li CY, Suardet L \& Little JB 1995 Potential role of WAF1/Cip1/p21 as a mediator of TGF-beta cytoinhibitory effect. Journal of Biological Chemistry 270 4971-4974.

Lin KH, Lin YW, Parkison C \& Cheng SY 1994 Stimulation of proliferation by $3,3^{\prime}, 5$-triiodo-L-thyronine in poorly differentiated human hepatocarcinoma cells overexpressing beta 1 thyroid hormone receptor. Cancer Letter 85 189-194.

Lin KH, Shieh HY \& Hsu HC 2000 Negative regulation of the antimetastatic gene Nm23-H1 by thyroid hormone receptors. Endocrinology 141 2540-2547.

Lin KH, Wang WJ, Wu YH \& Cheng SY 2002 Activation of antimetastatic Nm23-H1 gene expression by estrogen and its alpha-receptor. Endocrinology 143 467-475.

Lin KH, Chen CY, Chen SL, Yen CC, Huang YH, Shih CH, Shen JJ, Yang RC \& Wang CS 2004 Regulation of fibronectin by thyroid hormone receptors. Fournal of Molecular Endocrinology 33 445-458.

Martin-Castellanos C \& Moreno S 1997 Recent advances on cyclins, CDKs and CDK inhibitors. Trends in Cell Biology 7 95-98.

Massague J 1998 TGF-beta signal transduction. Annual Reviews of Biochemistry 67 753-791.

Nielsen NH, Arnerlov C, Cajander S \& Landberg G 1998 Cyclin E expression and proliferation in breast cancer. Analytical Cellular Pathology 17 177-188.

Pibiri M, Ledda-Columbano GM, Cossu C, Simbula G, Menegazzi M, Shinozuka H \& Columbano A 2001 Cyclin D1 is an early 
target in hepatocyte proliferation induced by thyroid hormone $\left(\mathrm{T}_{3}\right)$. FASEB Foumal 15 1006-1013.

Samuels HH, Stanley F \& Casanova J 1979 Depletion of $\mathrm{L}-3,5,3^{\prime}$-triiodothyronine and L-thyroxine in euthyroid calf serum for use in cell culture studies of the action of thyroid hormone. Endocrinology 105 80-85.

Sherr CJ 1996 Cancer cell cycles. Science 274 1672-1677.

Shih CH, Chen SL, Yen CC, Huang YH, Chen CD, Lee YS \& Lin KH 2004 Thyroid hormone receptor-dependent transcriptional regulation of fibrinogen and coagulation proteins. Endocrinology 145 2804-2814.

Shimizu M, Suzui M, Deguchi A, Lim JT, Xiao D, Hayes JH, Papadopoulos KP \& Weinstein IB 2004 Synergistic effects of acyclic retinoid and OSI-461 on growth inhibition and gene expression in human hepatoma cells. Clinical Cancer Research $\mathbf{1 0}$ $6710-6721$.

Sporn MB \& Roberts AB 1992 Transforming growth factor-beta: recent progress and new challenges. Fournal of Cell Biology $\mathbf{1 1 9}$ $1017-1021$.

Sumitani S, Kasayama S \& Sato B 1994 Thyroid hormone inhibits androgen-enhanced DNA synthesis in Shionogi carcinoma 115 cells without affecting autocrine growth factor mRNA expression. Fournal of Steroid Biochemistry and Molecular Biology 50 5-11.

Received in final form 3 October 2005

Accepted 26 October 2005

Made available online as an Accepted Preprint 28 October 2005 